$\$$ Research Square

\title{
Long-Term Straw Return Increases Biological Nitrogen Fixation by Increasing Soil Organic Carbon and Decreasing Available Nitrogen in Rice-Rapeseed Rotation
}

\author{
Huishan Fan \\ Zhejiang A \& F University \\ Shengqiang Jia \\ Zhejiang A \& F University \\ Man Yu \\ Institute of Environment, Resource, Soil and Fertilizer, Zhejiang Academy of Agricultural Sciences \\ Xijing Chen \\ Institute of Environment, Resource, Soil and Fertilizer, Zhejiang Academy of Agricultural Sciences \\ Alin Shen \\ Institute of Environment, Resource, Soil and Fertilizer, Zhejiang Academy of Agricultural Sciences \\ Yao Su ( $\nabla$ stellasu@sina.com ) \\ Institute of Environment, Resource, Soil and Fertilizer, Zhejiang Academy of Agricultural Sciences
}

\section{Research Article}

Keywords: Straw return, Soil depth, Potential nitrogen fixation rate, Nitrogen-fixing bacteria, Rice-rapeseed rotation, nifH gen

Posted Date: January 17th, 2022

DOI: https://doi.org/10.21203/rs.3.rs-1253413/v1

License: (ㅇ) (i) This work is licensed under a Creative Commons Attribution 4.0 International License. Read Full License 


\section{Abstract \\ Background}

Straw return can affect the soil nitrogen $(\mathrm{N})$ balance by changing soil carbon (C) and $\mathrm{N}$ components and contents. To understand how straw return affects soil $\mathrm{N}$ fixation capacity, relations between biological $\mathrm{N}$ fixation and changes in soil $\mathrm{C}$ and $\mathrm{N}$ contents at different depths need to be examined.

\section{Method}

Soil samples were collected at 20-cm intervals from 0 to $100 \mathrm{~cm}$ after 5 years of a rice-rapeseed rotation system with straw return (ST) and without (CK). Organic $\mathrm{C}$ and inorganic $\mathrm{N}$ contents, potential $\mathrm{N}$ fixation rate, and abundance and population composition of $\mathrm{N}$-fixing bacteria were analyzed at different soil depths.

\section{Results}

Compared with CK, ST increased soil organic C (SOC), particulate organic C (POC), mineral-associated organic C (MOC), and total N (TN) but decreased nitrate- $\mathrm{N}\left(\mathrm{NO}_{3}{ }^{-}-\mathrm{N}\right)$. Straw return also increased abundance of $\mathrm{N}$-fixing bacteria 2.9 to 18.2 -fold at depths from 0 to $40 \mathrm{~cm}$ and potential $\mathrm{N}$ fixation rate at $0-20 \mathrm{~cm}$ by $24.78 \%$, which was equivalent to an annual increase in $\mathrm{N}$ fixation of approximately 0.01 to $0.54 \mathrm{~kg} \cdot \mathrm{ha}^{-1}$. Long-term ST significantly affected the composition of $\mathrm{N}$-fixing bacteria at depths from 0 to $40 \mathrm{~cm}$.

\section{Conclusions}

Long-term straw return can effectively increase potential $\mathrm{N}$ fixation rate in soil and change the structure of the $\mathrm{N}$-fixing bacterial community by increasing SOC and decreasing $\mathrm{N}$ availability. The experiment showed that $\mathrm{SOC}, \mathrm{POC}, \mathrm{TN}$, and $\mathrm{NO}_{3}{ }^{-}{ }^{-} \mathrm{N}$ were the main environmental factors driving changes in abundance, activity, and population composition of soil $\mathrm{N}$-fixing bacteria under ST.

\section{Introduction}

Crop straw is an important agricultural resource because it is a rich source of organic carbon (C) and nutrients such as nitrogen (N), phosphorus (P), and potassium (K). In China, output of crop straw reached 1.15 billion tonnes in 2019, accounting for nearly one-third of the global output (Li et al., 2018, China Statistical Yearbook, 2020). Straw return is an important way to maintain and increase soil organic C (SOC) and is currently the most common method of using straw resources in China (Huang et al., 2019). Returning straw to the field can significantly improve soil physical properties (Zhang et al., 2017), promote fixation of SOC and N (Liu et al., 2014, Said-Pullicino et al., 2014), and change abundance, composition, and activity of soil bacterial populations (Guo et al., 2017). Thus, straw return has become one of the main types of human interference with soil $\mathrm{C}$ and $\mathrm{N}$ cycles in agroecosystems.

In farmland ecosystems, atmospheric $\mathrm{N}_{2}$ can be converted into inorganic $\mathrm{N}$ by lightning or by soil $\mathrm{N}$-fixing bacteria. The soil inorganic $\mathrm{N}$ can be directly absorbed by plants, converted into nitrite and nitrate by soil nitrifying bacteria before plant uptake, or converted into $\mathrm{N}_{2} \mathrm{O}$ or $\mathrm{N}_{2}$ by soil denitrifying bacteria (Kuypers et al., 2018). Soil $\mathrm{N}$-fixing bacteria can fix 60 to 100 million tonnes of $\mathrm{N}$ annually in farmlands and are one of the main sources of $\mathrm{N}$ in agroecosystems (Galloway et al., 2008). Nitrogen-fixing bacteria are an essential functional group in agroecosystems and include free-living, associated, and symbiotic N-fixing bacteria (Harindintwali et al., 2021). Free-living Nfixing bacteria such as Azotobacter and Bacillus can independently fix N, whereas associated N-fixing bacteria such as Enterobacter and Arthrobacter often live in the rhizosphere of plants. Symbiotic N-fixing microbes such as Rhizobium and Nostoc can only fix N in symbiosis with higher plants or other organisms (Ferreira et al., 2019). Ladha et al. (2016) assessed a 50-year global $\mathrm{N}$ budget and found that $80 \%$ of the $\mathrm{N}$ in rice was from biological $\mathrm{N}$ fixation. Under corn and wheat, up to $13 \mathrm{~kg} \cdot \mathrm{ha}^{-1} \mathrm{~N}$ was fixed in soil each year, of which nonsymbiotic $\mathrm{N}$-fixing microbes, i.e., free-living and associated, fixed approximately $50 \%$. Nonsymbiotic $\mathrm{N}$-fixing microbes are important in meeting the high $\mathrm{N}$ demand of plants and balancing $\mathrm{N}$ loss (Chalk et al., 2017). The nifH gene is a genetic marker of $\mathrm{N}$-fixing bacteria because it encodes the conserved subunit of the dinitrogenase iron protein (Lema et al., 2014). The gene also has one of the largest nonribosomal gene data sets for uncultured microorganisms, and thus, it is widely used in studies of soil $\mathrm{N}$-fixing bacteria (Yu et al., 2019). 
Biological $\mathrm{N}$ fixation is an energy-consuming process, and it is sensitive to changes in soil environmental factors, especially SOC (Fan et al., 2018) and inorganic $\mathrm{N}$ (Calderoli et al., 2017). Long-term (20 years) straw return increases SOC and soil $\mathrm{N}$ reserves, providing energy for $\mathrm{N}$-fixing bacteria and enhancing $\mathrm{N}$ mineralization, thereby increasing the abundance of nifH genes 1 to 1.5 -fold (Tang et al., 2017; Che et al., 2018; Xia et al., 2021) and $\mathrm{N}$ fixation activity in topsoil 59-68\% (Tang et al., 2017). However, after five consecutive years, straw return did not significantly affect $\mathrm{N}$ fixation rate or nifH gene copy number in topsoil of rice, because it increased soil $\mathrm{N}$ content and therefore $\mathrm{N}$ availability (Liao et al., 2018). Nitrogen-fixing bacteria could preferentially use exogenous $\mathrm{N}$ for vegetative reproduction, and therefore, reduced the energy-consuming $N$ fixation (Fan et al., 2018). Thus, straw return can have different effects on soil $N$ fixation, likely related to variation in $\mathrm{SOC}$ composition and $\mathrm{N}$ content.

Effects of straw return on SOC and N contents are closely related to factors such as amount of straw returned, number of years straw is returned, and depth of the soil layer. In summer maize-winter wheat rotation systems with long-term straw return, SOC, mineralassociated organic C (MOC) (Zhao et al., 2018), and dissolved organic C (DOC) in the 0-20- and 20-40-cm layers (Lu et al., 2021) increased by $15-26 \%, 13-31 \%$, and $15-20 \%$, respectively. However, He et al. (2019) reported that after 9 years of straw return, SOC increased significantly only in the $0-10-\mathrm{cm}$ soil layer, and the 10-50-cm layer was not affected. In addition, Gai et al. (2019) found that after returning wheat straw to the field for 27 years, total $N(T N)$, dissolved organic N (DON), and microbial biomass $N(M B N)$ increased significantly at $0-20 \mathrm{~cm}$. However, effects of straw return were limited in deeper soil from 40 to $200 \mathrm{~cm}$. Differences in effects of straw return on organic $\mathrm{C}$ and $\mathrm{N}$ contents in different soil layers likely affect the intensity of biological $\mathrm{N}$ fixation in different soil layers. Currently, most studies focus primarily on the effects of straw return on soil N fixation in the 0-20-cm layer (Rahav et al., 2016; Wang et al., 2017; Yang et al., 2018; Wang et al., 2019), and as a result, effects of long-term straw return on $\mathrm{N}$ fixation in deep soil layers have not been well documented. Such information is important in order to better understand $\mathrm{N}$ transformations in different soil layers with straw return and to effectively guide nutrient management of crops, especially those crops with more developed root systems, such as rapeseed and wheat. In addition, effects of SOC and $\mathrm{N}$ on $\mathrm{N}$-fixing bacterial populations have not been quantified.

Therefore, a five-year experiment was conducted to determine the effects of straw return on SOC and $\mathrm{N}$ contents at depths from 0 to 100 $\mathrm{cm}$. Potential $\mathrm{N}$ fixation rate and nifH copy number and composition of $\mathrm{N}$-fixing bacterial populations were determined at depths from 0 to $60 \mathrm{~cm}$. The objective was to reveal relations between $\mathrm{C}$ and $\mathrm{N}$ in different soil layers and biological $\mathrm{N}$ fixation potential. Redundancy and variance partition analyses were used to quantify contributions of soil $\mathrm{C}$ and $\mathrm{N}$ factors to variation in $\mathrm{N}$-fixing bacterial populations .

\section{Materials And Methods}

\section{Experimental design}

The experiment was conducted in Huangbilong Village $\left(29.02^{\circ} \mathrm{N}, 119.43^{\circ} \mathrm{E}\right)$, Jiangtang Township, Wucheng District, Jinhua City, Zhejiang Province, China, from June 2015 to May 2020. The area has a subtropical monsoon climate, with an annual average temperature of $17.3^{\circ} \mathrm{C}$ to $18.2^{\circ} \mathrm{C}$ and annual precipitation of $1,109.0$ to $1,305.2 \mathrm{~mm}$. A rice-rapeseed rotation system was used. The growing season of rice was from June to October, whereas that of rapeseed was from November to May of the following year. The soil type was loam soil. Before the experiment, topsoil (0-20 cm) chemical properties were the following: $\mathrm{pH} 6.55$, organic matter $32.1 \mathrm{~g}^{\cdot \mathrm{kg}^{-1}}, \mathrm{TN}^{1.24} \mathrm{~g} \cdot \mathrm{kg}^{-1}$, available $\mathrm{N}(\mathrm{AN}) 193.39 \mathrm{mg} \cdot \mathrm{kg}^{-1}$, available P $5.98 \mathrm{mg} \cdot \mathrm{kg}^{-1}$, and available $\mathrm{K} 72.5 \mathrm{mg} \cdot \mathrm{kg}^{-1}$.

Plots in the experiment were $2.7 \mathrm{~m} \times 7.5 \mathrm{~m}$. There were two treatments: CK (i.e., without straw return) and straw return (ST). There were three plots per treatment, for a total of six plots. Treatments were randomly distributed among the plots. In ST, average rice straw returned to the field was $8,100 \mathrm{~kg} \cdot \mathrm{ha}^{-1}$, whereas rapeseed straw input was approximately $6,150 \mathrm{~kg} \cdot \mathrm{ha}{ }^{-1}$. The depth of returned straw was $20 \mathrm{~cm}$. In the rice season, $\mathrm{N}$ fertilizer amount was $270 \mathrm{~kg} \cdot \mathrm{ha}^{-1}$, with $40 \%$ applied as basal fertilizer, $30 \%$ as tiller fertilizer, and $30 \%$ as ear fertilizer. Potassium fertilizer $\left(\mathrm{K}_{2} \mathrm{O}\right)$ amount was $108 \mathrm{~kg} \cdot h \mathrm{a}^{-1}$, of which $50 \%$ was tiller fertilizer and $50 \%$ was ear fertilizer. Phosphate fertilizer $\left(\mathrm{P}_{2} \mathrm{O}_{5}\right)$ was applied at $67.5 \mathrm{~kg} \cdot \mathrm{ha}^{-1}$ as base fertilizer. In the rapeseed season, $\mathrm{N}$ fertilizer was applied one time at $51.75 \mathrm{~kg} \cdot \mathrm{ha} \mathrm{a}^{-1}$ as base fertilizer. Potassium fertilizer amount was $112.5 \mathrm{~kg} \cdot \mathrm{ha}^{-1}$, with $40 \%$ applied as basal fertilizer and $60 \%$ as topdressing. Other field management measures were consistent with local practices.

\section{Soil sample collection}

After harvest in May 2020, the five-point sampling method was used to collect soil cores (4-cm diameter) from each plot at five different depths $(0-20,20-40,40-60,60-80$, and $80-100-\mathrm{cm})$. After removing debris and plant residues, soil samples from the same soil layer at the five sample points in each plot were mixed evenly. One portion of the samples was stored at $4^{\circ} \mathrm{C}$ in a refrigerator and used to 
measure DOC, microbial biomass $\mathrm{C}(\mathrm{MBC}), \mathrm{MBN}$, ammonia $\mathrm{N}\left(\mathrm{NH}_{4}{ }^{+}-\mathrm{N}\right)$, nitrate $\mathrm{N}\left(\mathrm{NO}_{3}{ }^{-}-\mathrm{N}\right)$, and potential $\mathrm{N}$ fixation rate (PNFR). A second portion was stored at $-20^{\circ} \mathrm{C}$ until DNA extraction. The remaining portion was air-dried and screened through a 2-mm mesh to determine SOC, TN, AN, and particulate organic carbon (POC). Mineral-associated organic $\mathrm{C}$ was determined by subtracting POC from total SOC.

\section{Soil chemical properties}

Dissolved organic $\mathrm{C}$ was measured by the deionized water extraction method (Haynes and Francis, 1993). Microbial biomass C and MBN were extracted by the chloroform fumigation-extraction method (Vance et al., 1987). Particulate organic $C$ was measured by sodium hexametaphosphate dispersion (Cambardella and Elliott, 1992). Before measurement of SOC and TN, soil was air-dried and ground to pass through a $0.15-\mathrm{mm}$ sieve. An automatic element analyzer (Vario Isotope Cube, Elementar, Jena, Germany) was used to measure SOC and TN (Nelson and Sommers, 2005). Soil $\mathrm{NH}_{4}{ }^{+}{ }^{-} \mathrm{N}$ and $\mathrm{NO}_{3}{ }^{-} \mathrm{N}$ were extracted with $2 \mathrm{~mol} \cdot \mathrm{L}^{-1} \mathrm{KCl}$ and measured on an AA3 continuous flow analyzer (Auto Analyzer 3, Bra+Luebbe, Hamburg, Germany) (Liu, 1996). Available N content was determined by the alkaline solution diffusion method after samples were air-dried, ground, and sieved (Page et al., 1982).

\section{Measurement of potential nitrogen fixation rate}

According to the steps in Hsu and Buckley (2009), ${ }^{15} \mathrm{~N}$ labeling was used to determine PNFR. First, $5.0 \mathrm{~g}$ of fresh soil sample was put in a $100-\mathrm{mL}$ serum bottle, and soil water content was adjusted to $60 \%$ of field water holding capacity. The bottle was vacuumed and then filled with $20 \% \mathrm{O}_{2}(\mathrm{v} / \mathrm{v})$ and $80 \%{ }^{15} \mathrm{~N}_{2}(\mathrm{v} / \mathrm{v})$. This process was repeated three times for each sample. Unlabeled $\mathrm{N}_{2}$ was used in the control. Samples were incubated for 7 days at room temperature in a dark room. After incubation, samples were freeze-dried and screened through a $0.15-\mathrm{mm}$ sieve. Total $\mathrm{N}$ content and ${ }^{15} \mathrm{~N}$ abundance were determined by an elemental analyzer-isotopic ratio mass spectrometer technique. Based on the difference in ${ }^{15} \mathrm{~N}$ content between labeled and unlabeled samples, the PNFR $\left(\mu \mathrm{g}(\mathrm{N}) \cdot \mathrm{kg}^{-1} \cdot \mathrm{d}^{-1}\right)$ was calculated.

\section{Abundance and population composition of soil nitrogen-fixing bacteria}

DNA was extracted from soil samples, 1.0-1.5 g, with an E.Z.N.A. ${ }^{\circledR}$ soil DNA kit (Omega, Norcross, GA, USA). A Nanodrop 2000UV-VIS spectrophotometer (Thermo Scientific, Waltham, MA, USA) was used to determine DNA concentration and purity, which was then stored at $-80^{\circ} \mathrm{C}$. Sample DNA was measured using a MiSeq sequencing platform at Shanghai Majorbio Bio-pharm Technology (Shanghai, China), and the primer sequences were nifHF (5'-AAAGGYGGWATCGGYAARTCCACCAC-3') and nifHR (5'-

TTGTTSGCSGCRTACATSGCCATCAT-3') (Rösch et al., 2002).

Raw sequences were processed using the Quantitative Insights Into Microbial Ecology (QIIME) website (http://qiime.org/scripts/assign_taxonomy.html) and the UPARSE platform (version 7.0.1090; http://drive5.com/uparse/). Standard primer sets and bar codes were excluded, and sequences with quality scores less than 20 were removed. Sequences shorter than 50 bp or those containing unresolved nucleotides were also removed. Extracting nonrepetitive sequences from the optimized sequences was convenient in reducing redundant computation in the intermediate process of analysis, and single sequences without duplication were removed. According to $97 \%$ similarity, nonrepetitive sequences (excluding single sequences) were clustered into operational taxonomic units (OTUs), with chimeras removed in the clustering process to obtain representative sequences of OTUs. A representative sequence was selected for each OTU under default parameters, and each representative sequence was assigned taxonomy using the Ribosomal Database Project (RDP) Classifier (Ou et al., 2019). Taxonomic information was obtained, and the community composition of each sample was determined at phylum and genus levels. The OTUs in each replicate were analyzed for richness and diversity. The sobs, Chao, Simpson, and Shannon indices were calculated to assess the alpha diversity of $\mathrm{N}$-fixing bacteria, with sobs and Chao indices reflecting community richness and Shannon and Simpson indices estimating community diversity (Zheng et al., 2018).

Fluorescence quantitative PCR was used to determine the copy number of nifH genes in sample DNA, and the primers were the same as those used for sequencing. The PCR procedure was as follows: pre-denaturation at $95^{\circ} \mathrm{C}$ for $3 \mathrm{~min}$; then, 35 cycles of denaturation at $95^{\circ} \mathrm{C}$ for $30 \mathrm{~s}$, annealing at $57^{\circ} \mathrm{C}$ for $30 \mathrm{~s}$, and extension at $72^{\circ} \mathrm{C}$ for $30 \mathrm{~s}$; and a repair extension at $72^{\circ} \mathrm{C}$ for 8 min. Temperature range of the melt curve was $65^{\circ} \mathrm{C}$ to $95^{\circ} \mathrm{C}$; the temperature was increased in increments of $0.5^{\circ} \mathrm{C}$ and held for $5 \mathrm{~s}$ to collect data.

\section{Statistical analyses}

Statistical analyses were conducted using SPSS 20.0 software for Windows (SPSS Inc., Chicago, IL, USA). Levene's test (Lin et al., 2018) confirmed that all data met the assumptions of normality and homogeneity of variance required for ANOVA. One-way ANOVA and least 
significant difference (LSD) were used to assess significance of effects of ST and soil depth on soil C and N contents, PNFR, nifH gene copy number, and diversity of $\mathrm{N}$-fixing bacterial populations. Pearson correlations were used to test relations between different SOC and $\mathrm{N}$ components and PNFR, nifH gene copy number, and N-fixing bacteria in R with the "corrplot" package (https://corrplot.r-forge.rproject.org).

Differences in $\mathrm{N}$-fixing bacterial populations under different treatments were analyzed using principal coordinates analysis (PCoA) based on a Bray-Curtis distance matrix in R with the "vegan" package (Oksanen et al., 2019). Variance inflation factors were computed to confirm collinearities among environmental properties. Usually, environmental properties that have variance inflation factors (VIFs) greater than 10 are of little value. Environmental properties were selected by the functions envfit (permu $=999)$ and vif.cca in R with the "vegan" package and then were removed until all VIF values were less than 10 (Ji et al., 2020) (Table S1). Redundancy analysis was

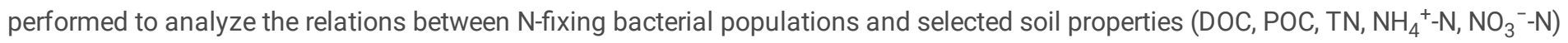
and assess the effects of long-term straw return on composition and structure of $\mathrm{N}$-fixing bacterial populations throughout the soil profile (Oksanen et al., 2019). The $\mathrm{P}$ and $R^{2}$ values indicated the significance and importance of the effect of a soil variable on $\mathrm{N}$-fixing bacterial populations. In addition, variance partitioning analysis (VPA) was also performed in order to quantify the contributions of soil organic $\mathrm{C}(\mathrm{SOC}, \mathrm{POC}, \mathrm{MOC}, \mathrm{DOC}, \mathrm{MBC})$ and $\mathrm{N}\left(\mathrm{TN}, \mathrm{NH}_{4}{ }^{+}-\mathrm{N}_{1} \mathrm{NO}_{3}{ }^{-}-\mathrm{N}\right)$ components to variation in composition of $\mathrm{N}$-fixing bacterial populations (Ji et al., 2020). Results were plotted using Microsoft Excel 2016 (Microsoft Corporation, Redmond, WA, USA), GraphPad Prism 8.0 (GraphPad Software, California, USA), and R (v 4.1.0).

\section{Results And Analysis}

\section{Effects of straw return on soil organic carbon and nitrogen components at different depths}

Straw returned changed SOC and N contents at different depths. Compared with CK, ST significantly increased SOC at depths from 0 to $80 \mathrm{~cm}, \mathrm{POC}$ at depths from 0 to $40 \mathrm{~cm}$, and MOC at depths from 20 to $60 \mathrm{~cm}$, with increases of $13.19-243.48 \%, 36.39-142.75 \%$, and $89.34-272.68 \%$, respectively. However, compared with CK, ST decreased DOC at depths from 0 to $60 \mathrm{~cm}$ and MBC at depths from 0 to 80 $\mathrm{cm}$, with decreases of $40.29-75.88 \%$ and $35.64-75.43 \%$, respectively. At the $80-100-\mathrm{cm}$ depth, there were no significant differences in contents of different SOC components between the two groups (Fig. 1).

Compared with CK, ST significantly increased TN content at depths from 0 to $80 \mathrm{~cm}$, with increases of $14.26-90.34 \%$. Compared with CK, ST significantly decreased MBN at depths from 0 to $80 \mathrm{~cm}$ and $\mathrm{NO}_{3}{ }^{-} \mathrm{N}$ and $\mathrm{AN}$ at depths from 0 to $60 \mathrm{~cm}$, with decreases of 41.83$72.98 \%, 12.92-61.87 \%$, and $12.99-67.80 \%$, respectively. Compared with CK, ST significantly decreased $\mathrm{NH}_{4}{ }^{+}-\mathrm{N} 11.61-24.80 \%$ at depths from 0 to $40 \mathrm{~cm}$, but significantly increased it $44.65 \%$ at $40-60 \mathrm{~cm}$.

\section{Effects of straw return on activity and abundance of nitrogen-fixing bacteria at different soil depths}

Potential $\mathrm{N}$ fixation rate, to a certain extent, characterizes activity of $\mathrm{N}$-fixing bacteria in soil. The PNFR decreased as soil depth increased, ranging from $0.14 \mu \mathrm{g}(\mathrm{N}) \cdot \mathrm{kg}^{-1} \cdot \mathrm{d}^{-1}$ to $3.08 \mu \mathrm{g}(\mathrm{N}) \cdot \mathrm{kg}^{-1} \cdot \mathrm{d}^{-1}$ (Fig. 2A). Compared with CK, PNFR increased significantly by $24.78 \%$ at 0-20-cm in ST, although there were no significant differences between treatments at depths from 20 to $60 \mathrm{~cm}$ (Fig. 2a). Correlations between PNFR and $\mathrm{C}$ and $\mathrm{N}$ contents were different in different soil layers (Fig. 3). At 0-20-cm, PNFR was positively correlated with SOC and TN and negatively correlated with $\mathrm{MBC}, \mathrm{NH}_{4}{ }^{+}-\mathrm{N}$, and $\mathrm{NO}_{3}{ }^{-}{ }^{-} \mathrm{N}$. At 20-60-cm depths, PNFR was only negatively correlated with $\mathrm{NH}_{4}{ }^{+}-\mathrm{N}$ (Fig. 3).

Similar to changes in PNFR, the abundance of nifH N-fixing bacteria also decreased as soil depth increased (Fig. 2b). Compared with CK, copy numbers of the nifH gene in $0-20$ - and $20-40-\mathrm{cm}$ soil layers increased by 2.9 and 18.2 -fold, respectively. The nifH gene copy numbers in different soil layers were significantly positively correlated with $\mathrm{SOC}, \mathrm{MOC}$, and TN and significantly negatively correlated with DOC, MBC, MBN, $\mathrm{NH}_{4}{ }^{+}-\mathrm{N}, \mathrm{NO}_{3}{ }^{-}-\mathrm{N}$, and AN (Fig. 3).

\section{Effects of straw return on population composition of nifH nitrogen-fixing bacteria at different soil depths}

Compared with CK, ST significantly increased the sobs index of N-fixing bacteria in 0-20- and 20-40-cm soil layers (Table 1), with increases of $11.13 \%$ and $28.55 \%$, respectively. However, the sobs index of $\mathrm{N}$-fixing bacteria in ST decreased in the $40-60-\mathrm{cm}$ soil layer compared within that in CK (Table 1). In addition, compared with CK, ST significantly increased Chao and Shannon indices of $\mathrm{N}$-fixing bacteria in the $20-40-\mathrm{cm}$ soil layer by $20.77 \%$ and $19.47 \%$, respectively. 
Table 1

Effects of long-term straw return (ST) and no straw return (CK) on a diversity and phylum-level composition of populations of nifH nitrogen-fixing bacteria at three soil depths from 0 to $60 \mathrm{~cm}$.

\begin{tabular}{|c|c|c|c|c|c|c|c|}
\hline \multirow{2}{*}{\multicolumn{2}{|c|}{$\begin{array}{l}\text { Diversity and phylum } \\
\text { components }\end{array}$}} & \multicolumn{6}{|l|}{ Treatment } \\
\hline & & \multicolumn{3}{|l|}{ CK } & \multicolumn{3}{|l|}{ ST } \\
\hline & & $0-20-\mathrm{cm}$ & $20-40-\mathrm{cm}$ & $40-60-\mathrm{cm}$ & $0-20-\mathrm{cm}$ & $20-40-\mathrm{cm}$ & $40-60-\mathrm{cm}$ \\
\hline \multirow{4}{*}{$\begin{array}{l}\text { Diversity } \\
\text { index }\end{array}$} & Sobs & $730 \pm 17 d$ & $706 \pm 15 d$ & $953 \pm 11$ a & $812 \pm 21 c$ & $908 \pm 27 b$ & $717 \pm 7 d$ \\
\hline & Chao index & $1151 \pm 56$ b & $1148 \pm 112 b$ & $1210 \pm 108 b$ & $1237 \pm 41 a b$ & $1386 \pm 88$ a & $1118 \pm 71 b$ \\
\hline & $\begin{array}{l}\text { Shannon } \\
\text { index }\end{array}$ & $5.10 \pm 0.11 \mathrm{a}$ & $4.34 \pm 0.27 b$ & $5.36 \pm 0.48 \mathrm{a}$ & $5.12 \pm 0.10 \mathrm{a}$ & $5.19 \pm 0.12 \mathrm{a}$ & $4.90 \pm 0.14 \mathrm{a}$ \\
\hline & $\begin{array}{l}\text { Simpson } \\
\text { index }\end{array}$ & $\begin{array}{l}0.018 \pm 0.002 \\
\mathrm{C}\end{array}$ & $0.120 \pm 0.011 a$ & $0.019 \pm 0.008 c$ & $0.022 \pm 0.002 c$ & $0.040 \pm 0.006 b$ & $0.033 \pm 0.008 \mathrm{bc}$ \\
\hline \multirow{3}{*}{$\begin{array}{l}\text { Relative } \\
\text { abundance } \\
\text { of phylum } \\
(\%)\end{array}$} & Proteobacteria & $\begin{array}{l}70.19 \pm \\
1.97 \mathrm{ab}\end{array}$ & $75.00 \pm 9.40 a b$ & $72.83 \pm 4.37 a b$ & $67.92 \pm 3.26 b$ & $77.66 \pm 1.35 a$ & $73.99 \pm 3.03 a b$ \\
\hline & $\begin{array}{l}\text { Unclassified } \\
\text { bacteria }\end{array}$ & $17.76 \pm 3.71 b$ & $14.99 \pm 2.69 b$ & $22.40 \pm 3.72 a$ & $17.08 \pm 2.12 b$ & $16.20 \pm 0.48 b$ & $14.84 \pm 1.14 b$ \\
\hline & Unclassified & $11.92 \pm 3.51 a$ & $7.31 \pm 1.18 b c$ & $4.10 \pm 0.77 c$ & $14.78 \pm 1.28 a$ & $5.81 \pm 1.81 \mathrm{c}$ & $10.72 \pm 4.26 a b$ \\
\hline
\end{tabular}

Proteobacteria was the main phylum of nifH N-fixing bacteria in soil layers in the upper $60 \mathrm{~cm}$ (relative abundance $67.92-77.66 \%$; Table 1). There was no significant difference between CK and ST. In addition, compared with CK, relative abundance of unclassified_k_norank_d_Bacteria (unclassified N-fixing bacterial phylum) decreased by $33.77 \%$ in ST; but relative abundance of unclassified increased by $161.25 \%$ at $40-60 \mathrm{~cm}$.

Thirty-nine genera of nifH $\mathrm{N}$-fixing bacteria were identified, and eight genera had relative abundances greater than $1 \%$ : unclassified_p_Proteobacteria, unclassified_k_norank_d_Bacteria, unclassified_c_Deltaproteobacteria, unclassified_d_unclassified, Geobacter, unclassified_c_Alphaproteobacteria, Anaeromyxobacter, and unclassified_o_Rhizobiales (Fig. 4a). Compared with CK, ST significantly increased the relative abundance of unclassified_c_Deltaproteobacteria at 0-20 cm by $44.3 \%$ (Fig. 4b), but that of Geobacter and Anaeromyxobacter decreased significantly by $17.03 \%$ and $21.05 \%$, respectively. In addition, compared with CK, ST also increased the relative abundance of Geobacter and unclassified_o_Rhizobiales at 20-40-cm and that of unclassified_c_Alphaproteobacteria at 40-60-cm.

In the PCoA, N-fixing bacteria in different soil layers were primarily clustered into two groups: (1) 0-60-cm in ST and 40-60-cm in CK, and (2) $0-20$ - and 20-40-cm in CK (Fig. 5a). The results indicated that the effect of ST on population composition of N-fixing bacteria was mainly concentrated at depths from 0 to $40 \mathrm{~cm}$. In the RDA (Fig. 5b), environmental factors explained $35.69 \%$ of the total variation in population composition of nifH N-fixing bacteria, with RD1 and RD2 explaining 31.25\% and 4.44\%, respectively. Among the factors, $\mathrm{POC}\left(R^{2}=0.413, P<0.05\right), \mathrm{TN}\left(R^{2}=0.531, P<0.01\right)$, and $\mathrm{NO}_{3}{ }^{-} \mathrm{N}\left(R^{2}=0.365, P<0.05\right)$ significantly affected the composition of $\mathrm{N}$-fixing bacterial populations. In addition, VPA was used to determine the relative contributions of organic C (DOC, MBC, POC, MOC, and SOC) and $\mathrm{N}\left(\mathrm{NH}_{4}{ }^{+}-\mathrm{N}, \mathrm{NO}_{3}{ }^{-}-\mathrm{N}\right.$, and $\left.\mathrm{TN}\right)$ components to the composition of $\mathrm{N}$-fixing bacterial populations (Fig. 5c). The variables explained $92.16 \%$ of the variation in $\mathrm{N}$-fixing bacterial populations, whereas $7.8 \%$ of the variation could not be explained. Changes in soil $\mathrm{N}$ and organic $\mathrm{C}$ contents after returning straw to the field explained $31.92 \%$ and $12.3 \%$, respectively, of the variation in composition of $\mathrm{N}$-fixing bacterial populations.

Correlations between soil factors in different soil layers and dominant genera of bacteria were inconsistent (Fig. 6). At 0-20 cm, Geobacter and Anaeromyxobacter were significantly negatively correlated with SOC and significantly positively correlated with DOC, $\mathrm{MBC}, \mathrm{MBN}$, and $\mathrm{NO}_{3}{ }^{-}-\mathrm{N}$, while unclassified_c_Deltaproteobacteria was significantly positively correlated with SOC and significantly 
negatively correlated with $\mathrm{DOC}, \mathrm{MBC}, \mathrm{MBN}$, and $\mathrm{NO}_{3}{ }^{-}-\mathrm{N}$. At 20-40 cm, Geobacter and unclassified_o_Rhizobiales were significantly positively correlated with $\mathrm{SOC}, \mathrm{MOC}, \mathrm{POC}$, and $\mathrm{TN}$ and significantly negatively correlated with $\mathrm{DOC}, \mathrm{MBC}, \mathrm{AN}, \mathrm{MBN}$, and $\mathrm{NO}_{3}{ }^{-}{ }^{-} \mathrm{N}$. $\mathrm{There}^{-}$ were no significant correlations between the other bacterial genera and soil factors.

\section{Discussion}

\section{Effects of straw return on activity and abundance of nitrogen-fixing bacteria at different soil depths}

In this study, PNFR decreased with increasing soil depth, with the rate decreasing from 3.08 to $0.14 \mu \mathrm{g}(\mathrm{N}) \cdot \mathrm{kg}^{-1} \cdot \mathrm{d}^{-1}$. Liao et al. (2018) used ${ }^{15} \mathrm{~N}_{2}$ tracing and estimated PNFRs were between 14.6 and $20.4 \mu \mathrm{g}(\mathrm{N}) \cdot \mathrm{kg}^{-1} \cdot \mathrm{d}^{-1}$ in paddy soil after 30 years of straw return. Therefore, in comparison, the rates in the present study were relatively low. The lower rates might be because nitrogenase in $\mathrm{N}$-fixing bacteria was sensitive to oxygen, and the catalytic reaction usually occurs under anaerobic conditions. Thus, the aerobic environment on dry land is not favorable for biological $\mathrm{N}$ fixation by $\mathrm{N}$-fixing bacteria (Keuter et al., 2014). Compared with CK, ST significantly increased PNFR at 0-20 cm but did not affect it at depths from 20 to $60 \mathrm{~cm}$. These results are consistent with those of Wang et al. (2019). However, in contrast to the $0-20-\mathrm{cm}$ layer in this study, they found soil biological $\mathrm{N}$ fixation mainly occurred in the $0-5-\mathrm{cm}$ soil layer. The difference might be because long-term straw return effectively increased organic $\mathrm{C}$ and $\mathrm{N}$ components in the 5-20-cm soil layer, which provided $\mathrm{C}$ and $\mathrm{N}$ sources for $\mathrm{N}$-fixing bacteria, thereby ensuring a good environment and energy supply to support them. Furthermore, $\mathrm{N}$ availability in soil can greatly affect activity of $\mathrm{N}$-fixing bacteria, with low $\mathrm{N}$ generally stimulating biological $\mathrm{N}$ fixation (Wang et al., 2017, Wang et al., 2019). Crop straw contains relatively low $\mathrm{N}$ and high $\mathrm{C}$ contents, and soil microorganisms absorb available $\mathrm{N}$ in soil to facilitate growth. Therefore, the significant decreases in soil $\mathrm{NO}_{3}{ }^{-}-\mathrm{N}$ and $\mathrm{NH}_{4}{ }^{+}-\mathrm{N}$ after straw return might also explain the increase in activity of $\mathrm{N}$-fixing bacteria in the $0-20-\mathrm{cm}$ soil layer. The decreases might also explain the negative correlations between PNFR and $\mathrm{NO}_{3}{ }^{-}-\mathrm{N}$ and $\mathrm{NH}_{4}{ }^{+}-\mathrm{N}$ at $0-20 \mathrm{~cm}$ and the positive correlations between PNFR and SOC and TN.

Similar to the effect on PNFR, ST effectively increased the abundance of nifH N-fixing bacteria at depths from 0 to $60 \mathrm{~cm}$. In general, most $\mathrm{N}$-fixing bacteria in soil are heterotrophic or facultative microorganisms. In ST, large amounts of organic $\mathrm{C}$ and energy are input to soil, which can effectively promote the growth of $\mathrm{N}$-fixing bacteria (Valiente et al., 1997; Che et al., 2018). However, high $\mathrm{NO}_{3}{ }^{-}-\mathrm{N}^{-}$and $\mathrm{NH}_{4}{ }^{+}-\mathrm{N}$ contents inhibit the growth of soil $\mathrm{N}$-fixing bacteria (Wang et al., 2015). Those observations are consistent with the findings of this study, because the nifH copy number was positively correlated with SOC, MOC, and TN and negatively correlated with $\mathrm{NO}_{3}{ }^{-}{ }^{-} \mathrm{N}^{-}$and $\mathrm{NH}_{4}{ }^{+} \mathrm{N}$.

Zhao et al. (2018) and Yang et al. (2021) showed that expression of functional genes and nitrogenase activity of $\mathrm{N}$-fixing bacteria were inhibited by high concentrations of $\mathrm{NO}_{3}{ }^{-} \mathrm{N}$ (Zuberer, 2021). In this study, ST led to significant decreases in nitrate $\mathrm{N}$ at depths from 0 to $60 \mathrm{~cm}$. The decrease could be explained by an increase in denitrification (Kakuda et al., 2000), which would also increase activity and abundance of $\mathrm{N}$-fixing bacteria in a negative feedback mechanism of the $\mathrm{N}$ cycle (Yang et al., 2021). In the rice and rapeseed rotation system, based on average soil bulk density of $1.2 \mathrm{~g} \cdot \mathrm{cm}^{-3}$, annual $\mathrm{N}$ fixation at different depths from 0 to $60 \mathrm{~cm}$ was approximately 2.70 $(0-20 \mathrm{~cm}), 0.58(20-40 \mathrm{~cm})$, and $0.13 \mathrm{~kg} \cdot \mathrm{ha}^{-1}(40-60 \mathrm{~cm})$ in ST, which was 0.01 to $0.54 \mathrm{~kg} \mathrm{~N} \cdot \mathrm{ha}^{-1}$ higher per year than that in CK. Compared with the amount of $\mathrm{N}$ applied, the amount of $\mathrm{N}$ fixation in the whole year was negligible, but it remains important to quantify all $\mathrm{N}$ inputs in order to further understand changes in the soil $\mathrm{N}$ cycle with long-term straw return. Although the increase was similar to the loss of nitrate $\mathrm{N}\left(0.36-0.68 \mathrm{~kg} \mathrm{~N} \cdot h \mathrm{a}^{-1}\right)$ in ST, changes in different forms of $\mathrm{N}$ can affect crop growth. In dryland crops, absorption of nitrate $\mathrm{N}$ is the main source of $\mathrm{N}$. Improvement in soil $\mathrm{N}$ fixation capacity in ST might not significantly change the reduction in nitrate caused by increased denitrification. Therefore, straw return may reduce the $\mathrm{N}$ supply for dryland crops. Consequently, changes in different forms of soil $\mathrm{N}$ should be fully considered when returning straw in order to facilitate efficient and reasonable management of $\mathrm{N}$ nutrition.

\section{Effects of straw return on population composition of nifH nitrogen-fixing bacteria}

In this study, 5 years of ST effectively increased diversity of $\mathrm{N}$-fixing bacteria at depths from 0 to $40 \mathrm{~cm}$, which is consistent with the results of Yang et al. (2018). The increase in diversity likely occurred primarily because most bacteria that can express the nifH gene are heterotrophic or facultative, and therefore, returned straw provided sufficient monosaccharides and polysaccharides for those bacteria (Rahav et al., 2016). The increase in diversity of $\mathrm{N}$-fixing microbial communities after straw return may lead to diversity in microbial processes and changes in soil characteristics, which are very important to soil health and plant productivity (Saleem et al., 2019). Therefore, in ST, the increase in diversity of $\mathrm{N}$-fixing microorganisms changed soil nutrients and organic $\mathrm{C}$ components, which provided 
bacteria, nutrients and $\mathrm{C}$ sources for biological nitrogen fixation under different environmental conditions, was conducive to maintaining soil biological $\mathrm{N}$ fixation after the change of environmental conditions, and helping to sustain rice-rapeseed rotation production systems.

Straw return not only changed the diversity of $\mathrm{N}$-fixing bacteria in soil but also affected population composition and structure. According to VPA, soil $\mathrm{N}(31.92 \%)$ explained a greater portion of changes in population composition of $\mathrm{N}$-fixing bacteria than that of SOC (12.3\%), suggesting that composition of $\mathrm{N}$-fixing bacterial populations in ST largely depended on the level of soil N (Ning et al., 2015). The RDA further validated that changes in $\mathrm{POC}, \mathrm{TN}$, and $\mathrm{NO}_{3}{ }^{-}-\mathrm{N}$ after long-term ST were the main factors affecting population composition of $\mathrm{N}$ fixing bacteria. These results are consistent with those of recent reports. Su et al. (2020) showed that POC generated by microorganisms in the process of assimilating straw $\mathrm{C}$ was the $\mathrm{C}$ source for $\mathrm{N}$-fixing bacteria (e.g., Bradyrhizobium, Burkholderia-Paraburkholderia, and Paraphaeosphaeria). Yang et al. (2018) also showed that $\mathrm{NO}_{3}{ }^{-}-\mathrm{N}$ content with straw return and inorganic fertilizer application was a significant factor affecting abundance and population composition of $\mathrm{N}$-fixing bacteria.

In the present study, differences in the composition of $\mathrm{N}$-fixing bacterial populations in ST primarily occurred at depths from 0 to $40 \mathrm{~cm}$. Straw return significantly increased the relative abundance of unclassified_c_Deltaproteobacteria at 0-20 cm, whereas it reduced that of Geobacter and Anaeromyxobacter. Deltaproteobacteria is an aerobic bacterium, whereas Geobacter (Wang et al., 2017) and Anaeromyxobacter (Aklujkar et al., 2011) are facultative anaerobic gram-negative bacteria (He and Sanford, 2003). Return of straw improves aeration of topsoil and thus, to a certain extent, increases the relative abundance of aerobic $\mathrm{N}$-fixing bacteria such as Deltaproteobacteria (Severin et al., 2015) but decreases that of anaerobic bacteria such as Geobacter and Anaeromyxobacter. In addition, Geobacter is an oligotrophic bacterium that is closely associated with N fixation activity (Hug et al., 2015), and its growth may be inhibited in nutrient-sufficient environments (Fan et al., 2018). Relative abundance of Geobacter at 0-20 cm was significantly negatively correlated with contents of SOC and TN in ST, whereas that at 20-40 cm was significantly positively correlated with SOC, POC, MOC, and TN. These results suggested that $C$ and $N$ contents at $20-40 \mathrm{~cm}$ inhibited growth and metabolism of this bacterium. The increase in organic $\mathrm{C}$ and $\mathrm{N}$ contents at $20-40 \mathrm{~cm}$ under ST could promote the growth of Geobacter and therefore also increased relative abundance of unclassified_o_Rhizobiales. Based on the above results and the RDA results, soil aeration, SOC, POC, $\mathrm{TN}$ and $\mathrm{NO}_{3}{ }^{-}-\mathrm{N}$ were identified as the main factors driving changes in population composition of nifH N-fixing bacteria and soil N-fixing capacity in ST.

In this research, $\mathrm{N}$ fixation was only examined following the rapeseed crop in the rice-rapeseed system, and $\mathrm{N}$ fixation following the rice crop remains unclear. Qin et al. (2016) showed that abundance and function of microorganisms involved in soil $\mathrm{N}$ cycling changed when paddy fields were converted to vegetables. Therefore, the influence of long-term straw return on soil $\mathrm{N}$-fixing microbial community structure in rapeseed or rice crop may directly or indirectly affect the next crop. Thus, future research should investigate the effects of long-term straw return on PNFR and $\mathrm{N}$-fixing microbial communities in rice crops as well as clarify changes in $\mathrm{N}$-fixing microbes between rice and rapeseed crops.

\section{Conclusions}

Long-term ST significantly affected abundance, activity, and population composition of $\mathrm{N}$-fixing bacteria by changing soil chemical properties at different depths, with effects reaching $20 \mathrm{~cm}$ or deeper. Straw return increased abundance, activity, and diversity of $\mathrm{N}$-fixing bacteria by increasing SOC, POC, and TN and by providing sufficient sources of C. Because of high $\mathrm{C}$ and low N contents of straw, soil available $\mathrm{N}$ content decreased, especially $\mathrm{NO}_{3}{ }^{-}-\mathrm{N}$ which might be accelerated by denitrification after straw return. Soil $\mathrm{NO}_{3}{ }^{-} \mathrm{N}^{-}$was also an important factor affecting populations of $\mathrm{N}$-fixing bacteria. To summarize, straw return induced changes in soil organic $\mathrm{C}$ and $\mathrm{N}$ contents that regulated $\mathrm{N}$-fixing bacterial populations, which had an important role in maintaining the balance between soil $\mathrm{C}$ and $\mathrm{N}$. Therefore, for crop nutrient management, it was necessary to full consider the change of different forms of nitrogen levels in soil and the supply of nitrogen nutrition caused by straw returning.

\section{Declarations}

\section{Author contributions}

Huishan Fan and Yao Su conceived and designed the experiments; Huishan Fan and Shengqiang Jia conducted the experiments; Huishan Fan and Yao Su did the analysis and wrote the main manuscript text; Ma Yu, Xijing Chen and Alin Shen edited the manuscript. All authors contributed to discussion about the results and the manuscript. 


\section{Funding}

This work was financially supported by the China Natural Science Foundation Youth Fund Project (Grant NO. 41807034), the National Modern Agricultural Technology System of Wheat (Grant NO.CARS-3), and Agricultural Science and Technology project in Ping hu (Grant NO.PH2020004).

\section{Declaration of Competing Interest}

The authors have no competing interests to declare that are relevant to the content of this article.

\section{References}

1. Aklujkar M, Young ND, Holmes D, Chavan M, Risso C, Kiss HE, Han CS, Land ML, Lovley DR (2011) The genome of Geobacter bemidjiensis, exemplar for the subsurface clade of Geobacter species that predominate in $\mathrm{Fe}(\mathrm{III})$ reducing subsurface environments. BMC Genomics.11,490. https://doi.org/10.1186/1471-2164-11-490

2. Calderoli PA, Collavino MM, Behrends KF, Morrás HJM, Aguilar M (2017) Analysis of nifH-RNA reveals phylotypes related to Geobacter and Cyanobacteria as important functional components of the N2-fixing community depending on depth and agricultural use of soil. MicrobiologyOpen. 5, e00502. https://doi.org/ 10.1002/mbo3.502

3. Cambardella CA, Elliott ET, (1992) Particulate soil organic matter changes across a grassland cultivation sequence. Soil Sci Soc Am J. 56,777-783.https://doi.org/10.2136/sssaj1992.03615995005600030017x

4. Chalk PM, He JZ, Peoples MB, Chen DL, (2017) ${ }^{15} \mathrm{~N} 2$ as a tracer of biological $\mathrm{N}_{2}$ fixation: A 75-year retrospective. Soil Boil Biochem, 106,36-50. https://doi.org/10.1016/j.soilbio.2016.12.010

5. Che RX, Qin JL, Tahmasbianl I, Wang F, Zhou ST, Xu ZH, Cui XY (2018) Litter amendment rather than phosphorus can dramatically change inorganic nitrogen pools in a degraded grassland soil by affecting nitrogen-cycling microbes. Soil Boil Biochem.120,145152. https://doi.org/ 10.1016/j.soilbio.2018.02.006

6. Fan KK, Weisenhorn P, Gilbert JA, Shi Y, Bai Y, Chu HY (2018) Soil pH correlates with the cooccurrence and assemblage process of diazotrophic communities in rhizosphere and bulk soils of wheat fields. Soil Boil Biochem, 121,185-192. https://doi.org/10.1016/j.soilbio.2018.03.017

7. Ferreira CMH, Soares HMVM, Soares EV (2019) Promising bacterial genera for agricultural practices: An insight on plant growthpromoting properties and microbial safety aspects. Sci Total Environ.682,779-799. https://doi.org/10.1016/j.scitotenv.2019.04.225

8. Gai XP, Liu HB, Liu J, Zhai LM, Wang HY, Yang B, Ren TZ, Wu SX, Lei QL (2019) Contrasting impacts of long-term application of manure and crop straw on residual nitrate-N along the soil profile in the North China Plain. Sci Total Environ. 650, 22512259. https://doi.org/10.1016/j.scitotenv.2018.09.275

9. Galloway JN, Townsend AR, Erisman JW, Bekunda M, Cai ZC, Freney JR, Martinelli LA, Seitzinger SP, Sutton MA (2008) Transformation of the nitrogen cycle: recent trends, questions, and potential solutions. Sci.5878, 889-892. https://doi.org/ 10.1126/science.1136674

10. Guo ZB, Wan SX, Hua KK, Wang DZ, He CL, Guo XS (2017) Enhanced yields and soil quality in a wheat-maize rotation using buried straw mulch. J Sci Food Agr.10, 3333-3341. https://doi.org/10.1002/jsfa.8183

11. Harindintwali JD, Zhou JL, Muhoza B, Wang F, HerzbergerA, Yu XB (2021) Integrated eco-strategies towards sustainable carbon and nitrogen cycling in agriculture. J Environ Manage.293. https://doi.org/ 10.1016/j.jenvman.2021.112856

12. Haynes RJ, Francis GS (1993) Changes in microbial biomass C, soil carbohydrate composition and aggregate stability induced by growth of selected crop and forage species under field conditions. Eur J Soil Sci, 44, 665-675. https://doi.org/ 10.1111/j.13652389.1993.tb02331.x

13. He LY, Zhang AF, Wang XD, Li J, Hussain Q (2019) Effects of different tillage practices on the carbon footprint of wheat and maize production in the Loess Plateau of China. J. Clean. Prod.234, 297-305. https://doi.org/10.1016/j.jclepro.2019.06.161

14. He Q, Sanford RA, (2003) Characterization of Fe(III) Reduction by Chlororespiring Anaeromxyobacter dehalogenans. Applied and Environ Microb.69,2712-2718. https://doi.org/10.1128/AEM.69.5.2712-2718.2003

15. Hsu SF, Buckley DH (2009) Evidence for the functional significance of diazotroph community structure in soil. ISME J, 3, 124-136.

16. Huang XL, Cheng LL, Chien H, Jiang H, Yang XM, Yin CB (2019) Sustainability of returning wheat straw to field in Hebei, Shandong and Jiangsu provinces: A contingent valuation method. J CLEAN PROD. 213, 1290- 
1298.https://doi.org/10.1016/j.jclepro.2018.12.242

17. Hug L, Thomas B, Sharon I, Brown C, Sharma R, Hettich R, Wilkins M, Williams K, Singh A, Banfield J (2015) Critical biogeochemical functions in the subsurface are associated with bacteria from new phyla and little studied lineages: $\mathrm{N}$ - and $\mathrm{C}$-cycling organisms in the subsurface. Environ Microb.18,159-173. https://doi.org/10.1111/1462-2920.12930

18. Kakuda K, Ando H, Konno T (2000) Contribution of nitrogen absorption by rice plants and nitrogen immobilization enhanced by plant growth to the reduction of nitrogen loss through denitrification in rhizosphere soil. Soil Sci. Plant Nutr. 46, 601-610. https://doi.org/10.1080/00380768.2000.10409125.

19. Keuter A, Veldkamp E, Corre MD (2014) Asymbiotic biological nitrogen fixation in a temperate grassland as affected by management practices. Soil Boil Biochem. 70,38-46.. https://doi.org/10.1016/j.soilbio.2013.12.009

20. Kuypers MMM, Marchant HK, Kartal B (2018) The microbial nitrogen-cycling network. Nat Rev Microbiol. 5,263-276. https://doi.org/10.1038/nrmicro.2018.9

21. Ladha JK, Tirol-Padre A, Reddy CK, Cassman KG, Verma,S, Powlson DS, Kessel CV, Richter BD, Chakraborty D, Pathak H (2016) Global nitrogen budgets in cereals: A 50-year assessment for maize, rice and wheat production systems. Sci Rep 6, 19355.

22. Lema K, Willis BL, Bourne D (2014) Amplicon pyrosequencing reveals spatial and temporal consistency in diazotroph assemblages of the Acropora millepora microbiome. Environ. Microbiol.16, 3345-3359. https://doi.org/10.1111/1462-2920.12366

23. Li H, Dai MW, Dai SL, Dong XJ (2018) Current status and environment impact of direct straw return in China's cropland- A review. Ecotox Environ Safe.159, 293-300. https://doi.org/10.1016/j.ecoenv.2018.05.014

24. Liao HK, Li YY, Yao HY (2018) Fertilization with inorganic and organic nutrients changes diazotroph community composition and Nfixation rates. J Soils Sediments. 18, 1076-1086. https://doi.org/10.1007/s11368-017-1836-8

25. Lin YX, Ye GP, Liu DY, Ledgard S, Luo JF, Fan JB, Yuan LJ, Chen ZM, Ding WX (2018) Long-term application of lime or pig manure rather than plant residues suppressed diazotroph abundance and diversity and altered community structure in an acidic Ultisol. Soil Biol. Biochem.123, 218-228. https://doi.org/10.1016/j.soilbio.2018.05.018

26. Liu C, Lu M, Cui J, Li B (2014) Effects of straw carbon input on carbon dynamics in agricultural soils: a meta-analysis. Global Change Biol. 5, 1366-1381. https://doi.org/ 10.1111/gcb.12517

27. Liu GS (1996) Soil Physical-Chemical Analysis and Description of Soil Profiles. Standards Press of China, Beijing, China.

28. Lu TP, Wang XJ, Du ZL, Wu LP (2021) Impacts of continuous biochar application on major carbon fractions in soil profile of North China Plain's cropland: In comparison with straw incorporation. Agr Ecosyst Environ. 315, 107445.

https://doi.org/ 10.1016/j.agee.2021.107445

29. Ji LF, Ni K, Wu ZD, Zhang JW, Yi XY, Yang XD, Ling N, You ZM, Guo SW, Ruan JY (2020) Effect of organic substitution rates on soil quality and fungal community composition in a tea plantation with long-term fertilization. Biol Fertil Soils 56, 633646.https://doi.org/10.1007/s00374-020-01439-y

30. Nelson DW, Sommers LE (2005) Total carbon, organic carbon, and organic matter D.L. Spark (Ed.), Analysis of Soil and Plants Chemical Methods. SSSA Book Series: 5. Soil Science Society of America Inc. American Society of Agronomy Inc. Wisconsin, USA.

31. Ning QS, Gu Q, Shen JP, Lv XT, Yang JJ, Zhang XM, He JZ, Huang JH, Wang H, Xu ZH, (2015) Effects of nitrogen deposition rates and frequencies on the abundance of soil nitrogen-related functional genes in temperate grassland of northern China. J Soils Sediments 15. 694-704. https://doi.org/10.1007/s11368-015-1061-2

32. Ou T, Xu WF, Wang F, Strobel GA, Zhou ZY, Xiang ZH, Liu J, Xie J (2019) A microbiome study reveals seasonal variation in endophytic bacteria among different mulberry cultivars. Computational and Structural Biotechnology. 17, 1091-1100.

33. Oksanen J, Blanchet FG, Kindt R (2019) Vegan: community ecology package. R package version 2.5-6. https://CRAN.Rproject.org/package=vegan.

34. Page AL, Miller RH, Keeney Dennis R (1982) Methods of soil analysis. Catena. 42, 345-346. https://doi.org/ 10.2136/vzj2004.0722

35. Qin HL, Zhang ZX, Lu J, Zhu YJ, Webster R, Liu XL, Yuan HZ, Hou HJ, Chen CL, Wei WX (2016) Change from paddy rice to vegetable growing changes nitrogen-cycling microbial communities and their variation with depth in the soil. Eur J Soil Sci, 67,650-658. https://doi.org/10.1111/ejss.12365

36. Rahav E, Giannetto MJ, Bar-Zeev E (2016) Contribution of mono and polysaccharides to heterotrophic $\mathrm{N}_{2}$ fixation at the eastern Mediterranean coastline. Sci Rep. 6, 27858. https://doi.org/10.1038/srep27858

37. Rösch C, Mergel A, Bothe $H$ (2002) Biodiversity of denitrifying and dinitrogen-fixing bacteria in an acid forest soil. Appl Environ Microbiol. 68, 3818-3829. https://doi.org/10.1128/AEM.68.8.3818-3829.2002

Page $10 / 14$ 
38. Said-Pullicino D, Cucu MA, Sodano M, Birk JJ, Glaser B, Celi L (2014) Nitrogen immobilization in paddy soils as affected by redox conditions and rice straw incorporation. Geoderma. 228-229, 44-53. https://doi.org/ 10.1016/j.geoderma.2013.06.020

39. Saleem M, Hu J, Jousset A (2019) More Than the Sum of Its Parts: Microbiome Biodiversity as a Driver of Plant Growth and Soil Health. Annu Rev Ecol Evol S, 50, 145-168. https://doi.org/10.1146/annurev-ecolsys-110617-062605

40. Severin I, Bentzon-Tilia M, Moisander PH, Riemann, L (2015) Nitrogenase expression in estuarine bacterioplankton influenced by organic carbon and availability of oxygen. FEMS Microbiol Lett. 362, fnv105. https://doi.org/10.1093/femsle/fnv105.

41. Statistics Bureau of the People's Republic of China (2020) China Statistical Yearbook. China Statistics Press, Bei Jing, China.

42. Su Y, He ZC, Yang YH, Jia SQ, Shen AL (2020) Linking soil microbial community dynamics to straw-carbon distribution in soil organic carbon. Sci Rep.10. https://doi.org/ 10.1038/s41598-020-62198-2

43. Tang YF, Zhang MM, Chen AL, Zhang WZ, Wei WX, Sheng R (2017) Impact of fertilization regimes on diazotroph community compositions and $\mathrm{N}_{2}$ fixation activity in paddy soil. Agr Ecosyst Environ. 247,1-8. https://doi.org/ 10.1016/j.agee.2017.06.009

44. Valiente E, Quesada A, Prosperi C, Nieva M, Leganés F, Ucha A (1997) Short- and long-term effects of ammonium on photodependent nitrogen fixation in wetland rice fields of Spain. Biol Fertil Soils 24, 353-357. https://doi.org/10.1007/s003740050257

45. Vance ED, Brookes PC, Jenkinson DS (1987) An extraction method for measuring soil microbial biomass C. Soil Boil Biochem.19, 703-707. https://doi.org/ 10.1016/0038-0717(87)90052-6

46. Wang C, Zheng MM, Song WF, Wen SL, Wang BR, Zhu CQ, Shen RF (2017) Impact of 25 years of inorganic fertilization on diazotrophic abundance and community structure in an acidic soil in southern China. Soil Boil Biochem.113,240249. https://doi.org/10.1016/j.soilbio.2017.06.019

47. Wang DZ, Sun RB, Guo XS, Chu HY (2015) Effects of long-term application of chemical and organic fertilizers on the abundance of microbial communities involved in the nitrogen cycle. Appl Soil Ecol.95,171-178. https://doi.org/10.1016/j.apsoil.2015.06.010

48. Wang XJ, Liu BJ, Ma J, Zhang YH, Hu TL, Zhang H, Feng YC, Pan HL, Xu ZW, Liu G, Lin XW, Zhu JG, Bei QC, Xie ZB (2019) Soil aluminum oxides determine biological nitrogen fixation and diazotrophic communities across major types of paddy soils in China. Soil Boil Biochem. 131, 81-89. https://doi.org/10.1016/j.soilbio.2018.12.028

49. Xia YH, Chen XB, Zheng SM, Gunina A, Ning Z, Hu YJ, Tang HM, Rui YC, Zhang ZH, He HB, Huang DY, Su YR (2021) Manure application accumulates more nitrogen in paddy soils than rice straw but less from fungal necromass. Agr Ecosyst Environ. 319: 107575. https://doi.org/ 10.1016/j.agee.2021.107575

50. Yang L, Bai JS, Zeng NH, Zhou X, Liao YL, Lu YH, M.Rees R, Nie J, Cao WD (2018) Diazotroph abundance and community structure are reshaped by straw return and mineral fertilizer in rice-rice-green manure rotation. Appl Soil Ecol.136,11-

20. https://doi.org/10.1016/j.apsoil.2018.12.015

51. Yang L, M.Rees R, Nie J, Xu CX, Cao WD (2021) Carbon substrates exert a stronger role than mineral nitrogen application in structuring soil diazotroph communities during Chinese milk vetch growth. Appl Soil Ecol.

158,103778. https://doi.org/10.1016/j.apsoil.2020.103778

52. Yu LL, Tang YL, Wang ZG, Guo YG, Wang JW (2019) Nitrogen-cycling genes and rhizosphere microbial community with reduced nitrogen application in maize/soybean strip intercropping. Nutr Cycl Agroecosys,113, 35-49. https://doi.org/10.1007/s10705-0189960-4

53. Zhang M, Cheng G, Feng H, Sun BH, Zhao YZ, Chen HX, Chen J, Dyck M, Wang XD, Zhang JG, Zhang AF (2017) Effects of straw and biochar amendments on aggregate stability, soil organic carbon, and enzyme activities in the Loess Plateau, China. Environ Sci Pollut R. 11,10108-10120. https://doi.org/ 10.1007/s11356-017-8505-8

54. Zhao HL, Shar AG, Li S, Chen YL, Shi JL, Zhang XY, Tian, XH (2018) Effect of straw return mode on soil aggregation and aggregate carbon content in an annual maize-wheat double cropping system. Soil Tillage Res. 175, 178-186.

https://doi.org/ 10.1016/j.still.2017.09.012

55. Zheng W, Zhao ZY, Gong QL, Zhai BN, Li ZY (2018) Responses of fungal-bacterial community and network to organic inputs vary among different spatial habitats in soil. Soil Biol $\otimes$ Biochem, 125: 54-63. https://doi.org/10.1016/j.soilbio.2018.06.029

56. Zuberer D A (2021) Biological dinitrogen $\left(\mathrm{N}_{2}\right)$ fixation: introduction and nonsymbiotic. Principles and Applications of Soil Microbiology (Third Edition). 423-453. https://doi.org/10.1016/B978-0-12-820202-9.00016-2

\section{Figures}

Page 11/14 

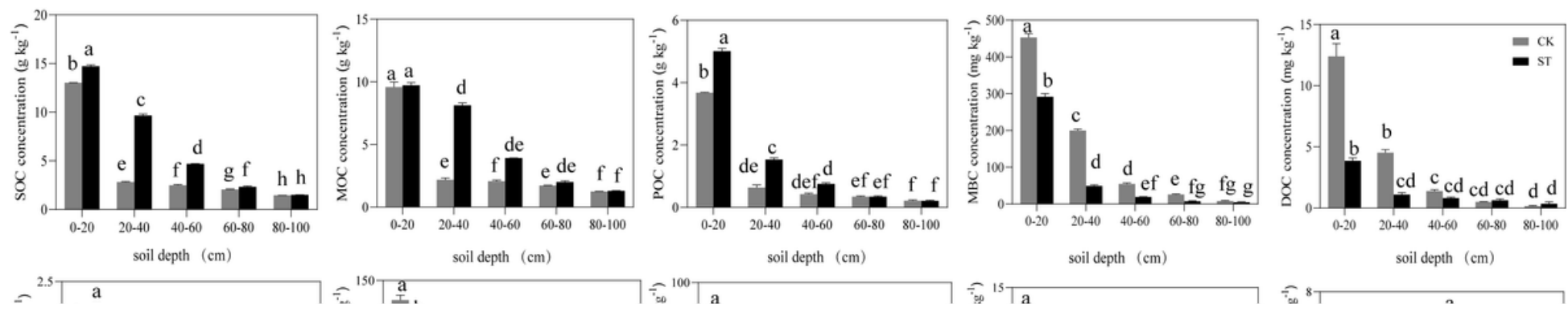

Figure 1

Effects of long-term straw return (ST) and no straw return (CK) on organic carbon and nitrogen components at different depths in soil from 0 to $100 \mathrm{~cm}$. Error bars indicate the SE of means $(n=3)$, and different lowercase letters above columns mean significant differences between treatment $(p<0.05)$.

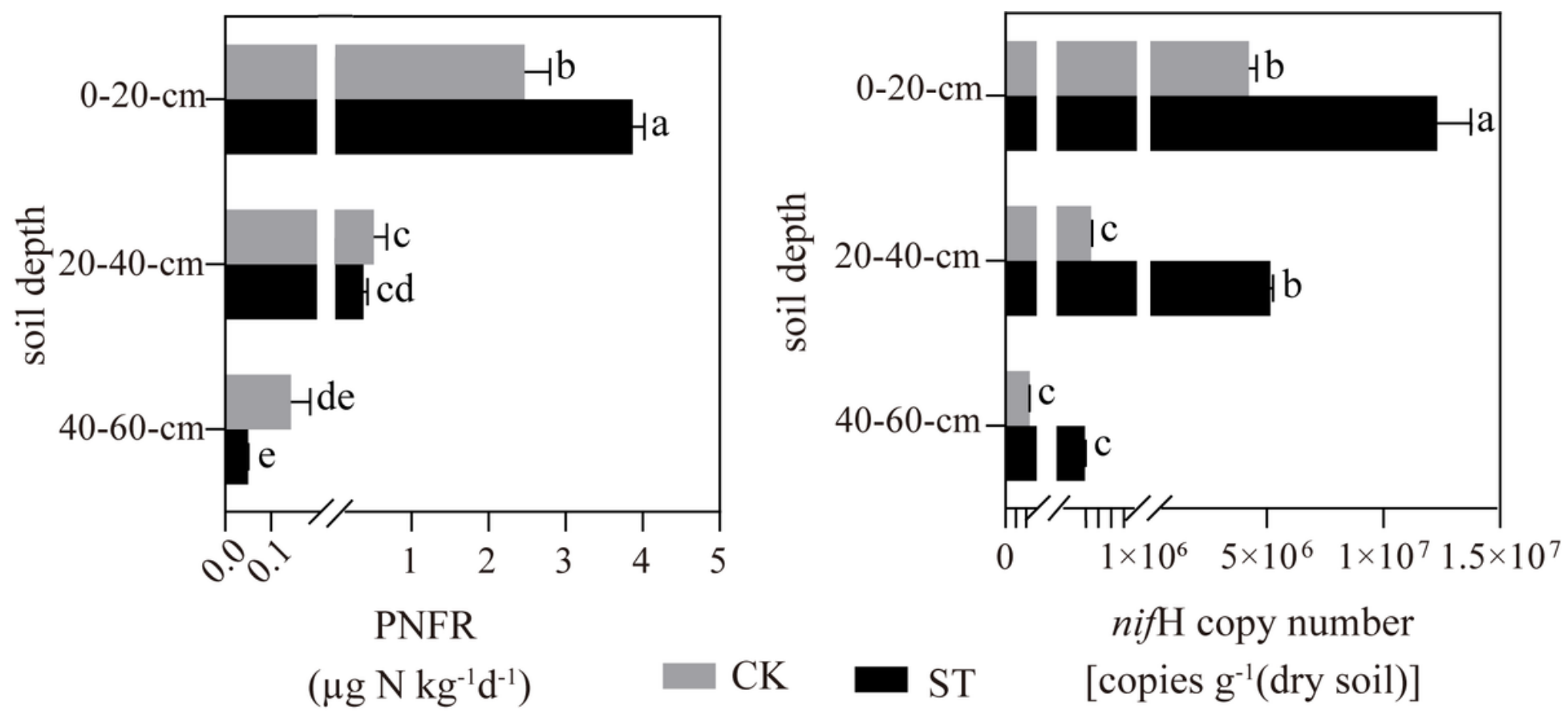

Figure 2

Comparison of effects of straw return (ST) and no ST (CK) on potential nitrogen fixation rate (PNFR, $\mu \mathrm{N} \mathrm{kg} \mathrm{k}^{-1} \mathrm{~d}^{-1}$ ) and copy number of the nifH gene (copy g ${ }^{-1}$ dry soil) at three soil depths from 0 to $60 \mathrm{~cm}$. Error bars indicate the $S E$ of means $(n=3)$, and different lowercase letters above columns mean significant differences between treatment $(p<0.05)$. 


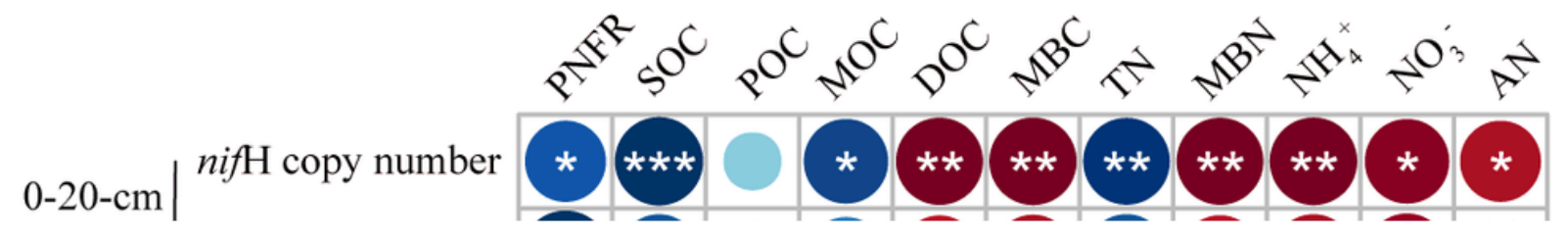

\section{Figure 3}

Pearson correlation matrix between soil chemical properties and nifH gene copy number and potential nitrogen fixation rate (PNFR) at three soil depths from 0 to $60 \mathrm{~cm}$. Data are means of 3 replicates. Blue and red circles denote positive and negative correlations, respectively. Large to small circles and dark to light color indicate high to low correlations.

\section{Figure 4}

Comparison of effects of straw return (ST) and no ST (CK) on (A) relative abundance (\%) of dominant genera and (B) significantly different bacterial genera composing nifH nitrogen-fixing bacterial populations at three soil depths from 0 to $60 \mathrm{~cm}$. Bars in blue and red represent the treatment with and without straw inputs, respectively. P value $<0.05$ indicates significant differences between CK and ST treatment.

\section{Figure 5}

Comparisons of populations of soil nitrogen-fixing bacteria in straw return (ST) and without (CK) treatments at three soil depths from 0 to $60 \mathrm{~cm}$. (a) Principal coordinates analysis (PCoA) of differences in population composition of soil N-fixing bacteria. (b) Redundancy analysis of population composition of nitrogen-fixing bacteria and soil chemical factors. (c) Variance partition analysis of effects of organic carbon and nitrogen on population composition of nitrogen-fixing bacteria. 
(a) $0-20-\mathrm{cm}$

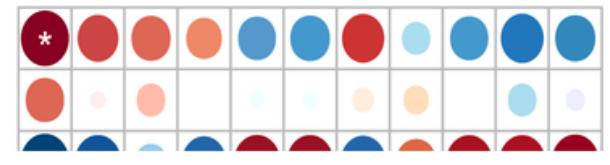

(b) $20-40-\mathrm{cm}$

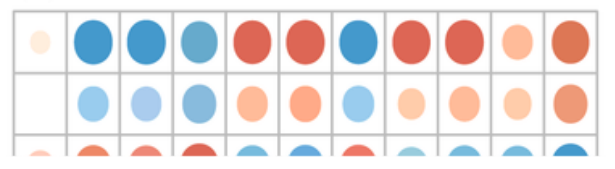

unclassified_p__Proteobacteria unclassified_k_norank_d_Bacteria

\section{Figure 6}

Pearson correlation matrix between soil chemical properties and dominant genera of nitrogen-fixing bacteria at 0-20 $\mathrm{cm} \operatorname{depths}(A)$ and 20-40 cm depths(B). Data are means of 3 replicates. Blue and red circles denote positive and negative correlations, respectively.

\section{Supplementary Files}

This is a list of supplementary files associated with this preprint. Click to download.

- Supplementary.docx 